\title{
6. COMPOSITION AND ORIGINS OF LAMINAE IN LATE QUATERNARY AND HOLOCENE SEDIMENTS FROM THE SANTA BARBARA BASIN'
}

\author{
David Bull ${ }^{2}$ and Alan E.S. Kemp²
}

\begin{abstract}
Late Quaternary and Holocene sediments from the Santa Barbara Basin have been analyzed using back-scattered electron imaging (BSEI) techniques to identify the origins of laminae and document intra- and interannual ocean/climate variability over the last glacial cycle. Laminae observed in X-ray radiography and BSEI are entirely defined by variations in the relative abundance and grain size of biogenic and terrigenous components. There is no evidence to suggest that bacterial mat mediation may have played a role in lamina formation. The simplest lamination type comprises silt-rich. silt-poor couplets that originate from seasonal variation in the supply of silt to the basin. The second lamination type contains an additional lamina of diatom ooze to form terrigenous-sediment diatomaceous triplets. The thicker diatom ooze laminae commonly exhibit a vertical succession of diatom floras, which represents intra-annual variation in productivity. The variation in thickness and assemblage of diatom ooze laminae is probably a function of the amount of diatom flux, which is controlled by upwelling-driven primary productivity in the basin. Laminated sediments deposited during cooler periods generally contain thicker diatom ooze laminae. consistent with more vigorous regional circulation and increased upwelling.
\end{abstract}

\section{INTRODUCTION}

Laminated marine sediments provide the highest resolution information available for reconstruction of ancient ocean and climate variability. Recent development and application of scanning electron microscope (SEM)-based analytical techniques has led to a fuller realization of the potential of laminated sediments as paleoceanographic indicators (Kemp, 1990; Kemp and Baldauf, 1993; Brodie and Kemp, 1994) and includes the potential to record information on intra-annual variability comparable to sediment trap time series (Pike and Kemp, 1993).

Holocene laminated sediments from the Santa Barbara Basin have been the subject of paleoceanographic study for some time (see Lange and Schimmelmann, 1994, and references therein). The new sedimentary record from Site 893 presents the first opportunity to study the late Quaternary sedimentary record over the last glacial cycle. Although there have been several studies of high-resolution variability in the Holocene laminated sequences (e.g., Soutar and Crill. 1977; Pisias, 1978; Baumgartner et al., 1992), few have carried out studies at the scale of individual laminae (Lange et al., 1987). A prerequisite for correct interpretation of the laminated sediment record is an adequate understanding of lamina fine structure and origins, including timing of lamina formation. The laminae observed in Holocene sediments of the Santa Barbara Basin are widely interpreted to represent annual deposition (Krishnaswami et al., 1973). Various mechanisms of lamina formation have been proposed, including seasonally varying sources of input (Emery and Hülsemann, 1962), bacterial mat response to seasonal changes in deposition (Soutar and Crill, 1977) and annual cycles of bottom-water oxygen replenishment and depletion leading to bacterial mat mediation (Reimers et al., 1990).

'Kennett. J.P.. Baldauf, J.G.. and Lyle. M. (Eds.). 1995, Proc. ODP. Sci. Results, 146 (Pt. 2): College Station. TX (Ocean Drilling Program).

Department of Oceanography. University of Southampton, Southampton, SO17 IBJ, United Kingdom.
Although some conventional secondary electron imagery has been undertaken (Reynolds and Gorsline, 1992), which, by itself, cannot adequately resolve laminae, little high-resolution back-scattered electron imagery (BSEI) of these sediments has been undertaken (Lange and Schimmelmann, 1994). The purpose of this paper is to report the results of preliminary analysis of laminated sediments from the Santa Barbara Basin at Site 893 using BSEI techniques.

\section{GENERAL SEDIMENTOLOGY}

The sediments from Site 893 consist of two three-stage sedimentary cycles. Each cycle is composed of a basal intermittently laminated sequence, a massive nonlaminated sequence, and a relatively thinner laminated sequence (Kennett, Baldauf, et al., 1994). The laminated to massive clays, silty clays, and diatomaceous muds are punctuated by discrete sand beds and by distinctive gray, sometimes graded, clayey silts that occur in a variety of thicknesses from lamina scale (see "Event Beds" section below) to thicker beds. The general sedimentology and depositional history of Site 893 is summarized by Behl (this volume).

\section{SOURCE OF MATERIAL}

The sediments examined in this study were selected from laminated Subunits IA and ID, and laminated sequences within intermittently laminated Subunits IC and IF. A total of 68 polished thin sections (PTS), containing in excess of 2000 laminae, were prepared from material obtained from 12 core intervals. In addition, more than 100 raw sediment samples were also prepared for topographic SEM study.

\section{METHODS}

BSEI work was performed on both PTS and raw sediment samples. Raw sediment samples were split in half and one half processed 


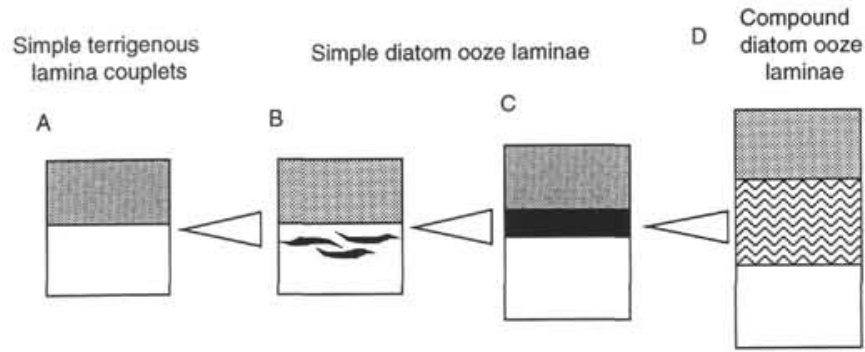

Increased opal preservation from increased productivity and flux

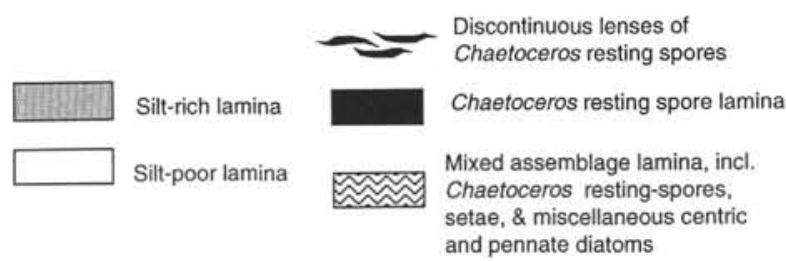

Figure 1. Schematic diagram illustrating the various stages of diatom ooze laminae development observed in Santa Barbara Basin sediments. A. Simple terrigenous silt-rich. silt-poor terrigenous couplets containing fragmented diatoms but with no separate diatom ooze component. B. Discontinuous lensoidal patches and stringers of Chuetoceros resting stages within the silt-poor lamina. C. Continuous diatom ooze lamina formed from Chaetoceros resting-stages. D. Complex ooze lamina exhibiting vertical succession of the floral assemblage and formed from various centric and pennate species.

to produce a PTS, whereas the counterpart was retained to provide material for subsequent topographic work.

Batches of sediment for PTS processing were vacuum-dried prior to being placed in a Logitech vacuum impregnator. The chamber was pumped down to $10^{-6} \mathrm{mb}$ prior to the introduction of low-viscosity epoxy resin. Once impregnated, the blocks were sectioned, mounted on glass microscope slides, and polished to a submicron finish. Slides were coated with $5 \AA$ carbon film prior to analysis in a JEOL JSM6400 SEM fitted with a solid state BSE detector.

Diatom identification was aided by topographic work conducted in BSEI mode in a JEOL 5300 low-vacuum SEM. The advantage of using a low-vacuum SEM was that "wet," uncoated sediment samples could be analyzed, eliminating the time-consuming preparation required for studying topographic specimens in high-vacuum conditions. The use of low-vacuum techniques incurs slight penalties in terms of reduced resolution and increased susceptibility to specimen charging. These were not found to be serious handicaps. Optimal results were obtained when individual laminae of interest were split horizontally, prior to mounting on standard pin stubs. This made the maximal surface area of each lamina available for study.

\section{LAMINA COMPONENTS}

Laminae may be composed of terrigenous couplets or mixed terrigenous-biogenic triplets. Couplets consist of alternate silt-rich, siltpoor laminae (Fig. 1; Pl. 5, Fig. 1), whereas triplets contain an additional lamina of diatom ooze (Fig. 1; Pl. 5, Fig. 2). In triplet sequences the thickness of the diatom ooze lamina is the main variable, and ranges from thin $(<20 \mu \mathrm{m}$ thick) discontinuous stringers and ribbons
(PI. I, Fig. 5) to discrete laminae up to $2 \mathrm{~mm}$ in thickness (Fig. 2). Variability in thickness is less pronounced in couplet sequences in which variation is largely confined to variations in the thickness and grain size of the silt-rich component.

\section{Terrigenous Laminae}

In terrigenous laminae, clay is the dominant component. Silt-rich laminae are distinguished by a $20 \%$ to $40 \%$ silt component and are generally poorly sorted, with the silt grains evenly distributed within the clay. Both the silt-rich and clay-rich laminae contain sparse fragments of diatoms. Grading of the silt component is only exceptionally observed. Mineralogical work conducted by Fleischer (1972) suggests that the Santa Clara River is the major source of the silt component. River-borne silt is deposited on the shelf prior to remobilization, and subsequent deposition in the basin (Drake et al., 1972). Typical couplets are about $0.5 \mathrm{~mm}$ thick. In the silt-rich laminae the coarsest material occurs in laminated sediments deposited closest to glacial maxima, where material of very fine- to fine-sand grade is common. In the majority of silt-rich laminae, however, material is of the medium- to coarse-silt grade. A degree of internal variation in the thickness of silt-rich, silt-poor laminae is observed within terrigenous sequences. In well-developed terrigenous lamina sequences, groups of couplets form several light-dark series (PI. 5, Fig. 1). These are controlled by the abundance of material of the fine- and medium-silt grade. Groups of laminae richer in material of the finesilt grade appear lighter than those richer in coarse-silt grade material. In the sediments examined, terrigenous couplets are the less common laminae type, accounting for $40 \%$ of observed laminae. Within interglacial stages, however, terrigenous couplet sequences are prevalent. In general appearance, the Santa Barbara Basin silt-rich, siltpoor couplets closely resemble similar couplets described in late Quaternary sediments from the Peru margin (Brodie and Kemp, 1994).

\section{Event Beds}

Some thin sections examined contain thin laminae that were clearly not one of the normal lamina components described above. Their sharp contacts with the subjacent laminae suggest that these beds are generated by rapid depositional events. Two types are apparent. The first type are composed of terrigenous sediment ranging in grade from the coarser clay fractions to coarse silt; in contrast, the second type contains abundant diatom frustules. The fact that terrigenous event beds most commonly occur in terrigenous couplet laminated sequences, and that diatom-containing event beds are restricted to triplet laminated sequences, leads us to the conclusion that these beds are mainly derived from the reworking of preexisting basin deposits, and were not derived from exotic sources. In diatom-containing beds there is a link between the amount of diatomaceous material in the event bed and that in the underlying laminae.

\section{Composition of Diatom Ooze Laminae}

The diatom component of the laminated sequences is highly variable: it may be reduced to individual valves and scattered fragmented debris or discontinuous lenses or stringers within one of the terrigenous laminae (Fig. 1; Pl. 1, Fig. 5); alternatively, thick laminae of diatom ooze may exceed the thickness of the surrounding terrigenous couplet (Fig. 2; Pls. 4, 5). In exceptional cases, diatom ooze laminae may be up to $2 \mathrm{~mm}$ thick, and are clearly visible to the naked eye in the raw sediment samples. The more usual thickness range is from 0.25 to $0.75 \mathrm{~mm}$.

Some of the characteristic diatom species observed are displayed in Plates 1 and 2. The diatom component consists primarily of Chaetoceros spp. in the form of setae and/or resting stages. The weakly 
A

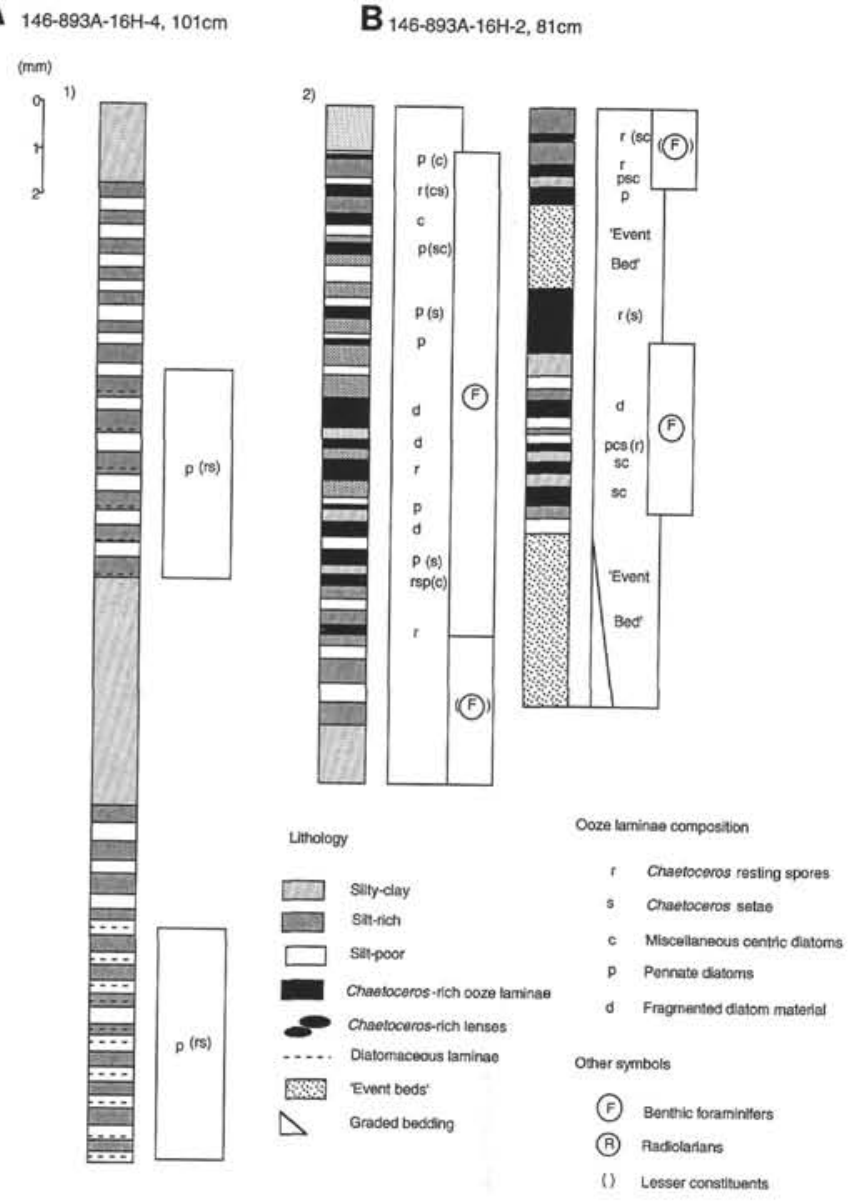

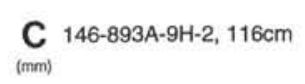

D $146-893 \mathrm{~A}-13 \mathrm{H}-7,31 \mathrm{~cm}$

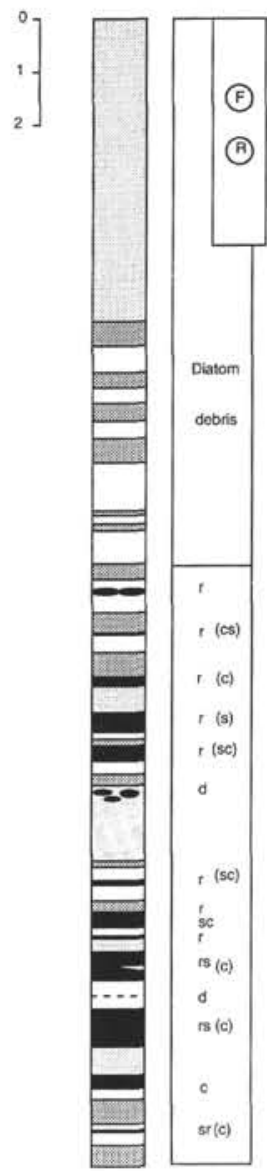

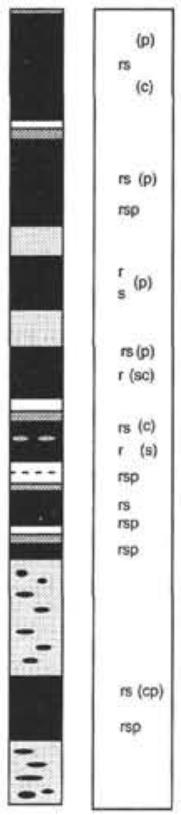

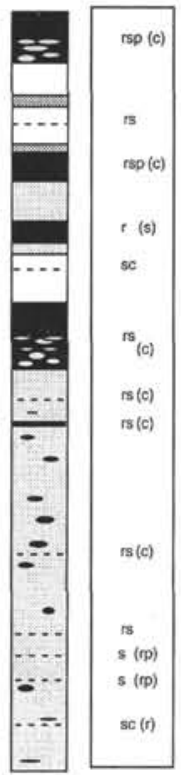

Figure 2. Logs of characteristic examples of laminates examined by this study. A. Thin packets of discontinuous diatomaceous laminae dominated by nonupwelling species in a sequence of variable lamina development. B. Sequence showing variable development of diatom ooze laminae (not containing typical upwelling species) and intercalated "event beds." C. Quite extensive development of thin, upwelling-generated, ooze laminae, and sporadic non-upwelling ooze laminae; ooze lamina decrease in thickness upsection. D. Sharp upward change from thin discontinuous diatomaceous laminae to thick ooze laminae associated with a general increase in diatom assemblage diversity.

silicified vegetative stages of Chaetoceros diatoms are very rare. The resting-stage assemblage is invariably dominated by Chaetoceros radicans. Chaetoceros vanheurckii, $C$. diadema, and $C$. didymus are less abundant constituents of ooze laminae. Preservation of resting stages is good. Within many Chaetoceros laminae, other centric and pennate diatoms form a lesser part of the assemblage. The most commonly observed species belong to the Thalassiosiracae and Coscinodiscacae groups (Pl. 2, Fig. 4). The quality of preservation of these centric diatoms is largely size dependent. The valves of larger species may occur as broken valves and detached girdles, whereas those of smaller species such as Thalassiosira oestrupii (Pl. 2, Fig. 3) are usually preserved intact. Less commonly observed are species belonging to the Stephanopyxis, Actinoptychus, and Cocconeis groups. In exceptional cases broken chains of Skeletonema costatum are also present. Pennate diatoms are less common than centrics within Chaetoceros laminae. The most commonly observed pennate species is Thalassionema nitzschioides (PI. 1, Fig. 4). In exceptional cases $T$. nitzschioides may be sufficiently abundant to form microlaminae in excess of $100 \mu \mathrm{m}$ in thickness (Pl. 2, Figs. 1, 2).

Ooze laminae composed of species other than Chaetoceros occur as isolated laminae within sequences of thick Chaetoceros laminae and, with greater frequency, in sequences containing thinner Chaeto- ceros laminae. Typically, these laminae are composed of Thalassiosiracae and Coscinodiscacae group diatoms.

Most diatom ooze laminae also contain varying amounts of terrigenous material. Coarse material, ranging from medium silt to very fine sand, occurs as individual grains. This is commonly most abundant in the uppermost section of the diatom ooze laminae. Finer, claygrade material occurs as lensoidal inclusions and, less frequently, may be sufficiently abundant to form a terrigenous-rich sublamina within the ooze lamina. In some cases this material is compacted in aggregates with varying amounts of fragmented biogenic material.

\section{MODE OF DEPOSITION OF DIATOM OOZE LAMINAE}

Before any paleoceanographic interpretation can be attempted, it is essential to know what exactly the preserved assemblage represents, and how the observed assemblage relates to the original live surface assemblage. Work conducted by Sancetta (1992) indicates that in terms of diversity, the diatom assemblage reaching the ocean floor is impoverished with respect to the surface community; and Reimers et al. (1990) showed that further dissolution of the diatom 


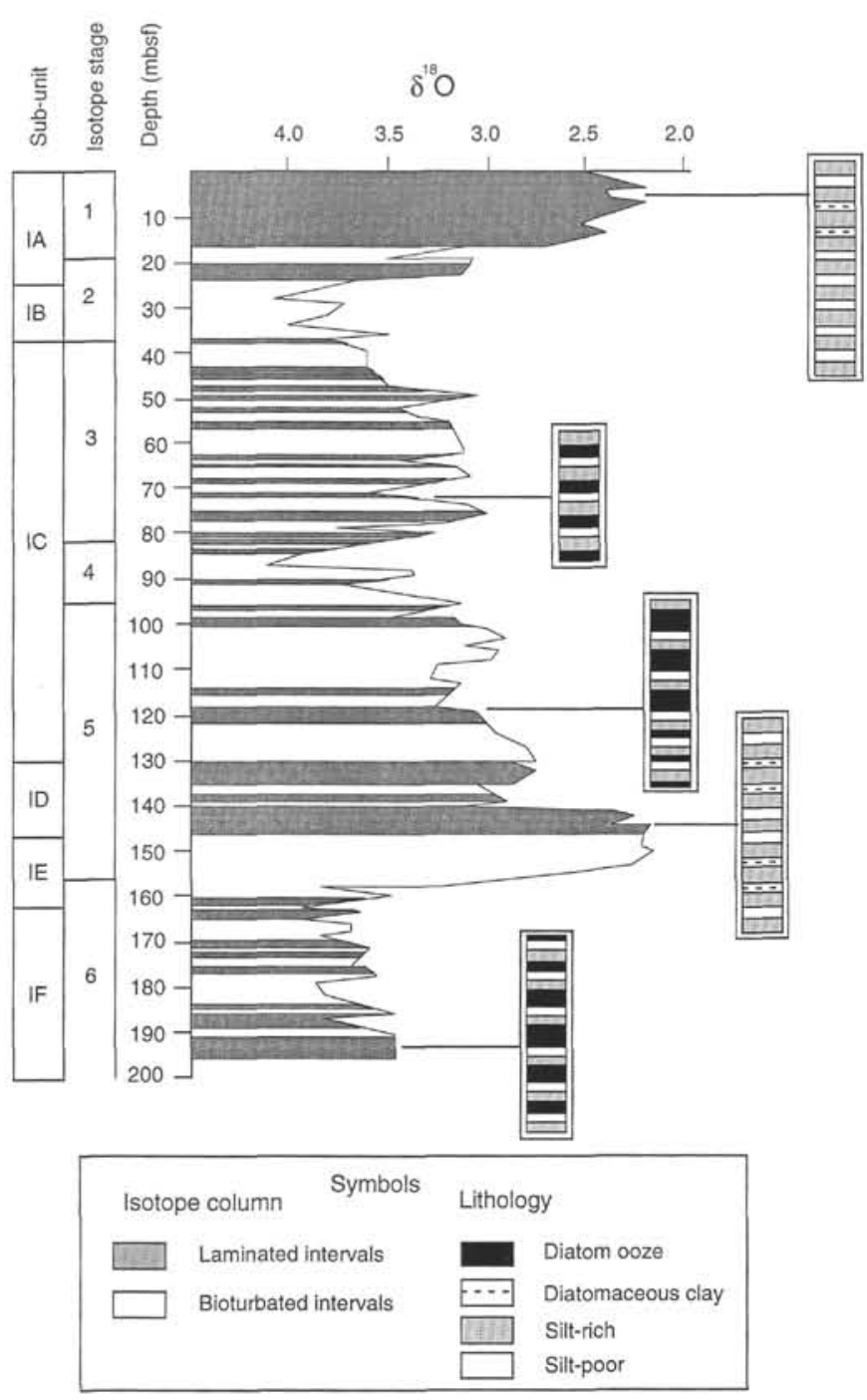

Figure 3. Chronology of laminated intervals within Hole 893A showing the general relationship between $\delta^{1 \times} \mathrm{O}$ values and the expression of laminated sequences. Also shown are typical examples of laminated sequences from differing stages in the glacial cycle. Diatom ooze laminae show the greatest development in isotopically cooler stages. Diatom ooze laminae from isotope Stage 3 tend to be rather thin. Diatom ooze laminae from isotope Stages 5 and 6 both show marked variations in the thickness of ooze laminae: for isotope Stage 5 sediments, this is manifest as episodic shifts, whereas in the case of isotope Stage 6 sediments, a pronounced rhythmic variation is sometimes observed. Lithologic units from Kennett, Baldauf, et al. (1994); stable isotope data from Kennett (this volume); age determinations by Ingram and Kennett (this volume).

assemblage occurs at and immediately below the sediment/water interface. Dissolution is minimized by rapid descent from the surface waters to the subjacent seafloor. Rapid sedimentation of diatoms may be effected by fecal pellets (Schrader, 1971), mass flocculation by way of marine snow (Alldredge and Gottschalk, 1989) or transparent exopolymer particles (Alldredge et al., 1993), and mass sinking of diatom mats (Sancetta et al., 1991; Kemp and Baldauf, 1993).
Although the role of fecal pellets in sedimentation of Santa Barbara Basin sediments has been documented in the sediment trap studies of Dunbar and Berger (1981), the intact nature of much of the diatomaceous material within the diatom ooze laminae (Pl. 2) suggests that this was not the principal mechanism of deposition. In a combined field and laboratory study of the fecal pellets of copepods (the most abundant metazoan oceanic zooplankton). Honjo and Roman (1978) showed that only skeletal material less than $10 \mu \mathrm{m}$ in size was preserved intact within fecal pellets, and that larger material was fragmented. Mixed terrigenous-diatomaceous pellets inferred to be fecal pellets, do occur in diatom ooze laminae, but only as a minor component. The fabric of this pelleted material is markedly different from that of the surrounding diatom ooze lamina material. The nonpelleted material, which comprises the bulk of the diatom ooze laminae, is characterized by a higher porosity, minimal fragmentation of the diatomaceous component, reduced terrigenous content, and in some cases, reduced abundance of coccoliths relative to the pelleted material. In view of the lack of extensive fragmentation of diatoms, it is considered that the characteristics of diatom ooze laminae are incompatible with deposition by packaging within fecal pellets as the major mechanism of deposition.

The bulk of biogenic material in diatom ooze laminae is derived from resting-stage forming Chaetoceros species, which characterize the second bloom stage of Guillard and Kilham (1977). Weakly silicified Stage 1, and residual Stage 3 assemblages are rarely preserved. Mass flocculation of Chaetoceros species diatoms in the modern Santa Barbara Basin has been described by Alldredge and Gottschalk (1989). The commonest species identified in modern flocs, Chaetoceros radicans, is also the commonest species identified in the upper Pleistocene diatom ooze laminae. In certain diatom ooze laminae, high porosity, tangled masses of setae are observed. Typically, these are in the order of $100 \mu \mathrm{m}$ in length, although occasionally these masses may exceed a millimeter in length. These masses frequently contain attached resting stages and a small amount of entrained terrigenous detritus. The high porosity of these structures and the intact nature of the diatomaceous material precludes fecal pelleting as an origin.

The occurrence of Thalassionema within Chaetoceros-dominated laminae provides further evidence for a mass-flocculation of the Chaetoceros component. The pennate diatom Thalassionema nitzschioides is a colonial species in which small numbers of individuals are joined by mucilage pads (Round et al., 1990). Where Thalassionema occurs as a lesser constituent within Chaetoceros laminae, Thalassionema valves occur as small bundles of a dozen or more individuals. We suggest that this bundling occurs as a result of the Thalassionema colonies being entrained within sinking Chaetoceros flocs. The greater strength of the setae and mucilage-bound Chaetoceros floc prevents the disruption of the Thalassionema colony.

From the above evidence, we believe that mass flocculation of bloom-forming diatoms produced most of the diatom ooze laminae. The rapid descent of flocculated and aggregated diatoms at rates probably exceeding $100 \mathrm{~m} /$ day (Alldredge and Gottschalk, 1989), bypassing grazing, explains the intact nature of diatom frustules within laminae.

\section{VERTICAL SUCCESSION IN DIATOM OOZE LAMINAE}

In several Chaetoceros-rich diatom ooze laminae, vertical successions were observed. In some cases, a basal setae-rich sublamina is overlain by a sublamina dominated by resting spores. Setae-rich sublaminae may correspond to the flocculation of setae-bound Chaetoceros vegetative stages during the second stage of the diatom bloom succession of Guillard and Kilham (1977). The absence of the vege- 
tative stage frustules from this portion can be attributed to dissolution. Resting stages are produced in response to increased nutrient depletion following seasonal reduction of upwelling, and corresponds to the third stage of Guillard and Kilham (1977). Many of the thicker diatom ooze laminae are more composite, containing four or more identifiable sublaminae (Pl. 3), and appear to indicate a more complex sequence of bloom events. A detailed analysis of the internal successions in diatom species within laminae is currently in progress.

\section{FORAMINIFERS}

Benthic foraminifers are a common minor constituent of laminites. Rotaline types, dominated by Bolivina seminuda, are most abundant. In addition, a small number of textularian types were also observed. The latter are most abundant in the Holocene and isotope Stage $5 e$ sediments. The abundance of rotaline foraminifers is highly variable.

In laminated sequences, benthic foraminifer abundance appears to be related to diatom abundance. Foraminifers are rare in triplet sequences in which well-developed diatom ooze laminae occur. Conversely, in triplet sequences in which diatom laminae are poorly developed, benthic foraminifers commonly occur in great profusion. The scarcity of benthic foraminifers in sequences with well-developed ooze laminae may reflect development of more fully anoxic conditions than those that currently occur in the basin related to increased organic flux.

On a lamina scale, foraminifers are largely confined to terrigenous laminae. In terrigenous laminated couplet sequences, foraminifers tend to be concentrated in the summer clay-rich laminae. This is consistent with the work of Reimers et al. (1990), who found that, in the modern basin, the maximal abundance of foraminifers coincided with minima in basin oxygenation created by the input of bloom material into the basin and the cessation of Pacific Intermediate Water flow into the basin.

\section{BACTERIAL MATS}

The role of bacterial mats in promoting lamina formation in the present-day Santa Barbara Basin has been highlighted by several authors (e.g., Soutar and Crill, 1977; Williams and Reimers, 1982; Reimers et al., 1990). However, these mats have poor long-term preservation potential. There is no evidence from the scanning electron microscope fabric studies of this research for the preservation of mats in the sediments examined. Furthermore, in contrast to the conclusions of Reimers et al. (1990), we find no need to appeal bacterial mat mediation to explain the formation of the laminae described herein. Physical characteristics of laminae such as porosity are controlled by variations in lamina constituents (i.e., fluctuations in the relative proportions, grain size, and sorting of terrigenous and biogenic material).

\section{LAMINAE GROUPINGS}

The two end-members of laminae style are terrigenous couplets and terrigenous-ooze triplets. If an annual periodicity for silt-rich, silt-poor couplets and terrigenous-diatomaceous triplets is assumed, couplet sequences may persist for at least $50 \mathrm{yr}$, and triplet sequences may persist for at least $120 \mathrm{yr}$. Using data gathered from all the specimens examined, a series of features can be documented that characterizes the evolution from couplet to triplet sequences. Logs of laminated intervals displaying some of these features are included in Figure 2.
Regardless of diatom abundance, ooze laminae always occur in sequences. In sediments where diatom abundance is too low to form discrete ooze laminae, diatoms are concentrated in lensoidal accumulations or ribbons and stringers that, superimposed on the background clay deposition, form thin diatomaceous laminae. In these sediments, terrigenous-diatomaceous triplet sequences are short-lived, spanning $3 \mathrm{yr}$ to $7 \mathrm{yr}$, and occur sporadically within terrigenous couplet sequences.

In sediments where there is a sufficient abundance of diatoms to form thin, discrete, ooze laminae, the triplet sequences are closer spaced and persist over longer periods. A certain amount of internal variation is apparent in these sequences, which frequently contain marked minima in the thickness of ooze laminae.

A range of internal features is apparent in sequences of well-developed ooze laminae. These sequences can be divided into a succession of packets, each defined by a particular range of diatom ooze laminae thickness. Episodic shifts in the intensity of upwelling are indicated by changes in the thickness of ooze laminae between packets (PI. 4). A feature common to all well-developed triplet laminated sequences is the presence of distinct minima in the thickness of ooze laminae, or complete absence of ooze laminae. The spacing of these minima shows some relation to sediment age (Fig. 3). In isotope Stage 5 sediments two groups of minima occur. The more common group is centered around a decadal periodicity. The less common group most commonly occurs over a 5-yr to 7-yr periodicity. In isotope Stage 6 sediments, the decadal periodicity is largely absent, and the shorter periodicity is manifest over a greater range of $4 \mathrm{yr}$ to $8 \mathrm{yr}$. In certain isotope Stage 6 sediments, the transition from maximal to minimal ooze laminae thickness exhibits a striking rhythmic pattern (PI. 5, Fig. 2). Assessing the significance of these minima requires further work. The shorter-term range of periodicities covers the frequencies of recurrence commonly cited for El Niño-Southern Oscillation (ENSO) events (Douglas, 1981). In the modern-day Santa Barbara Basin, ENSO events are characterized by the replacement of the normal Chaetoceros-dominated upwelling assemblage by a more diverse assemblage of warmer water, more oceanic affinities (e.g., Coscinodiscus sp.; Pl. 2, Fig. 4; Lange et al., 1987) and flushing of basin waters (Berelson, 1991). In some of the sediments that date from isotope Stage 3, minima in the thickness of the ooze lamina appear to be associated with a non-Chaetoceros assemblage.These lamina consist of the valves of large centric diatoms of Coscinodiscacae and Thalassiosiracae groups distributed within the clay-rich terrigenous laminae. In the majority of minima, however, there is no assemblage change, merely a reduction in the amount of Chaetocerosderived material present.

\section{CONCLUSIONS}

The examination of late Quaternary and Holocene laminated sediments from the Santa Barbara Basin using BSEI has been used to elucidate the compositional variation and origins of laminae and to relate variations in lamina style to the paleoceanographic and paleoclimatic history.

We have found no evidence for the preservation of bacterial mats, or indeed, any evidence to suggest that bacterial mats have played a role in lamina formation. The physical characteristics of laminae such as porosity are controlled by variations in lamina constituents (i.e., fluctuations in the relative proportions, grain size, and sorting of terrigenous and biogenic material).

The simplest laminae are couplets of silt-rich and silt-poor terrigenous sediment, around $0.5 \mathrm{~mm}$ thick, whose origins are best ascribed to the seasonal cycle of silt input from winter rains. Superimposed on these terrigenous couplets is a highly variable diatom ooze component. This varies from a discontinuous series of thin lenses or stringers of diatom ooze within silt-poor laminae to discrete, 
millimeter-thick, ooze laminae that give an overall triplet lamina bundle. The thicker diatom ooze laminae are commonly composite. showing a vertical succession in diatom species that records intra-annual variation in productivity.

Variation in the thickness of diatom ooze laminae probably relates to the amount of diatom flux, which is a function of upwelling-driven productivity in the basin. As a general pattern, laminated sediments deposited in cooler periods contain thicker diatom ooze laminae (Fig. 3 ), which is consistent with greater wind-driven upwelling intensity and productivity (although there are no laminae preserved in glacial periods due to increased basin oxygenation; see Kennett, this volume). This evidence is supported by the scarcity of benthic foraminifers in sequences of thick ooze laminae indicative of more fully anoxic conditions related to increased organic flux. There is considerable potential for further detailed studies of inter- and intra-annual variability and quantitative study of opal flux and paleoproductivity variation within these sediments.

\section{ACKNOWLEDGMENTS}

DB acknowledges receipt of a NERC Research Studentship. This study was supported by the award of NERC grants GST/02/820 and GR9/1347 to AESK. Attendance of AESK at the Site 893 description/sampling meeting was funded by the NERC ODP Science Program. We gratefully acknowledge the assistance of C. Lange in diatom identification and in the provision of sediment samples from the Holocene portion of Hole 893A, and S. King in the identification of foraminifers. Reviews by H. Schrader and D. Gorsline improved the quality of this manuscript.

\section{REFERENCES}

Alldredge, A.L., and Gottschalk, C.C., 1989. Direct observation of the mass flocculation of diatom blooms; characteristic settling velocities and form of diatom aggregates. Deep-Sea Res., 36:159-171.

Alldredge, A.L.. Passow, U., and Logan, B.E., 1993. The abundance and significance of a class of large, transparent organic particles in the ocean. Deep-Sea Res., 40:1131-1140.

Baumgartner, T.R., Soutar. A., and Ferreira-Bartrina, V.. 1992. Reconstruction of the history of the Pacific sardine and northern anchovy populations over the past two millenia from sediments of the Santa Barbara basin. California. Calif. Coop. Oceanic Fisheries Invest. Rep., 33:24 40.

Berelson, W.M., 1991. The flushing of two deep sea basins, Southern California Borderland. Limnol. Oceanogr. 36:1150-1166.

Brodie, I., and Kemp. A.E.S.. 1994. Variation in biogenic and detrital fluxes and formation of laminae in late Quaternary sediments from the Peruvian coastal upwelling zone. Mar. Geol.. 116:385-398.

Douglas, R., 1981. Paleoecology of continental margin basins: a modern case history from the borderland of Southern California. In Douglas, R.. Gorsline, D.S., and Colburn. I. (Eds.). Depositional Systems of Active Continental Margin Basins. Soc. Econ. Paleontol. Mineral., Pacific Sect. Short Course, $121-156$.

Drake, D.E., Kolpack. R.L., and Fischer, P.J.. 1972. Sediment transport on the Santa Barbara-Oxnard Shelf, Santa Barbara Channel, California. In Swift, D.J.P., Duane. D.B., and Pilkey, O.H. (Eds.), Shelf Sediment Transport: Process and Pattern: Stroudsburg. PA (Dowden. Hutchinson. and Ross), 307-331.
Dunbar, R.B., and Berger, W.H., 1981. Fecal pellet flux to modern bottom sediment of Santa Barbara Basin (California) based on sediment trapping. Geol. Soc. Am. Bull., 92:212-218.

Emery, K.O.. and Hülsemann, J., 1962. The relationships of sediments, life and water in a marine basin. Deep-Sea Res. Part A, 8:165-180.

Fleischer, P., 1972. Mineralogy and sedimentation history, Santa Barbara Basin, California. J. Sediment. Petrol.. 42:49-58.

Guillard, R.R.L., and Kilham, P., 1977. Ecology of marine planktonic diatoms. In Werner, D. (Ed.), The Biology of Diatoms. Botan. Monogr.. 13. Berkeley (Univ. Calif. Press), 470-483.

Honjo, S., and Roman, M.R., 1978. Marine copepod fecal pellets: production, preservation and sedimentation. J. Mar. Res., 36:45-57.

Kemp, A.E.S., 1990. Sedimentary fabric and variations in lamination style in Peru continental margin upwelling sediments. In Suess, E., von Huene. R., et al., Proc. ODP. Sci. Results, I12: College Station, TX (Ocean Drilling Program), 43-58.

Kemp, A.E.S., and Baldauf, J.G.. 1993. Vast Neogene laminated diatom mat deposits from the eastern equatorial Pacific Ocean. Nature, 362:141-144.

Kennett, J.P., Baldauf, J., et al., 1994. Proc. ODP, Init. Repts., 146 (Pt. 2): College Station, TX (Ocean Drilling Program).

Krishnaswami. S., Lal, D., Amin. B.S., and Soutar, A., 1973. Geochronological studies of the Santa Barbara Basin: Fe as a unique tracer for particulate settling. Limnol. Oceanogr., 18:763-770.

Lange, C.B., and Schimmelmann. A., 1994. Seasonal resolution of laminated sediments in Santa Barbara Basin: its significance in paleoclimatic studies. In Redmond, K.T., and Tharp. V.L. (Eds.). Proc. 10th Annu. Pac; Climate (PACLIM) Workshop. Tech. Rep.-Calif. Dep. Water Resour., 36:83-91.

Lange, C.B., Berger. W.H., Burke, S.K., Casey, R.E., Schimmelmann, A., Soutar, A., and Weinheimer, A.L., 1987. El Niño in Santa Barbara basin: diatom, radiolarian, and foraminiferan responses to the "1983 El Niño" event. Mar. Geol., 78:153-160.

Pike. J., and Kemp. A.E.S.. 1993. Complex signals from laminated sediments, Gulf of California. Eos, 74:363.

Pisias. N.G., 1978. Paleoceanography of the Santa Barbara Basin during the last 8000 years. Quat. Res., 10:366-384.

Reimers, C.E., Lange, C.B., Tabak, M., and Bernhard, J.M., 1990. Seasonal spillover and varve formation in the Santa Barbara Basin, California. Limnol. Oceanogr.. 35:1577-1585.

Reynolds, S., and Gorsline, D.S., 1992. Clay microfabrics of deep sea mud(stones), California Continental Borderland. J. Sediment. Petrol.. 62:41-53.

Round, F.E., Crawford, R.M., and Mann, D.G., 1990. The Diatoms: Biology and Morphology of the Genera: Cambridge (Cambridge Univ. Press).

Sancetta, C., 1992. Comparison of phytoplankton in sediment trap time series and surface sediments along a productivity gradient. Paleoceanography: 7:183-194.

Sancetta, C., Villareal, T., and Falkowski, P., 1991. Massive fluxes of rhizosolenid diatoms: a common occurrence? Limnol. Oceanogr.. 36:14521457.

Schrader, H., 1971. Fecal pellets: their role in the sedimentation of pelagic diatoms. Science, 174:55-57.

Soutar, A., and Crill, P.A., 1977. Sedimentation and climatic patterns in the Santa Barbara Basin during the 19th and 20th centuries. Geol. Soc. Am. Bull., 88:1161-1172.

Williams, L.A.. and Reimers, C.. 1982. Recognizing organic mats in deep water environments. Geol. Soc. Am. Abstr. Progr., 14:647.

Date of initial receipt: 29 August 1994

Date of acceptance: 20 March 1995

Ms 146SR-271 


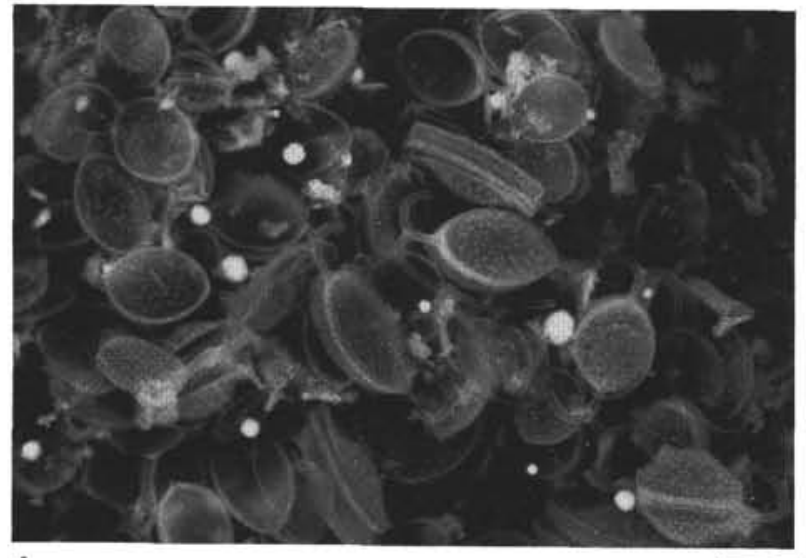

1

$10 \mu \mathrm{m}$
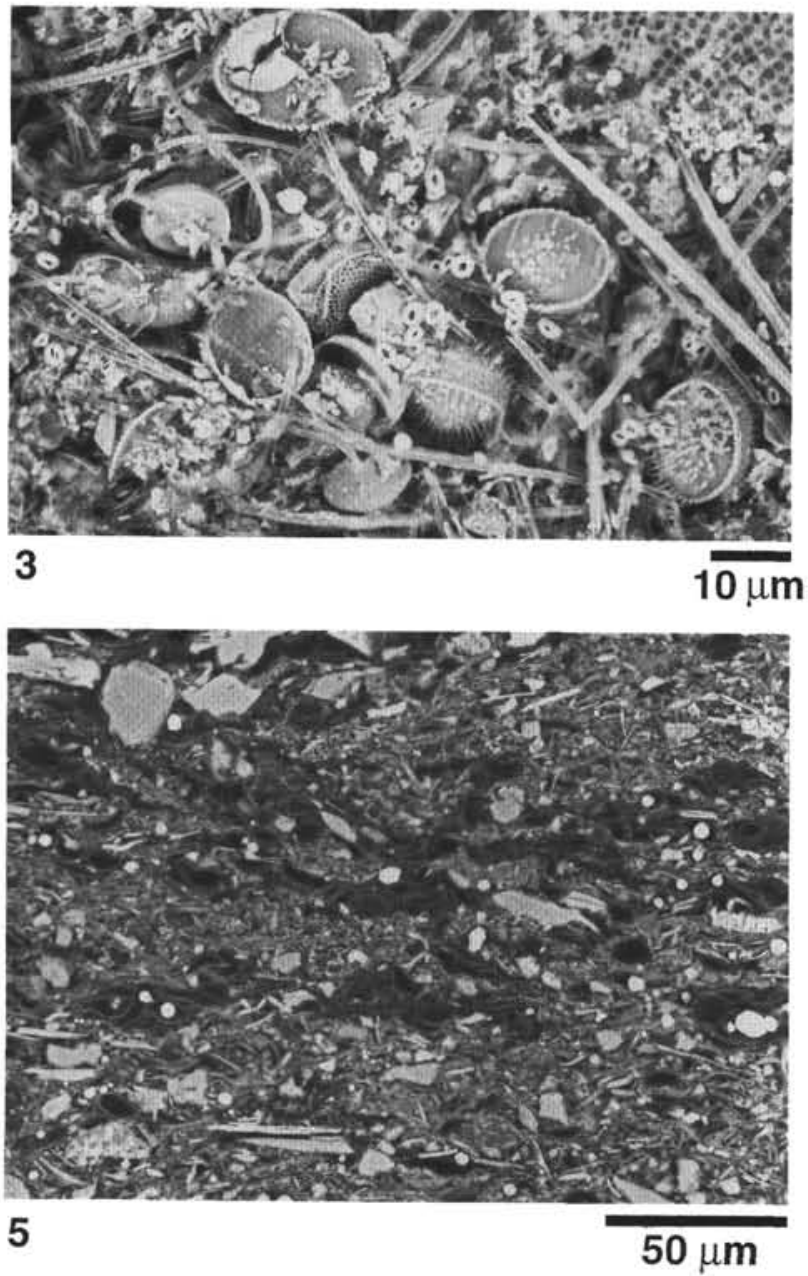

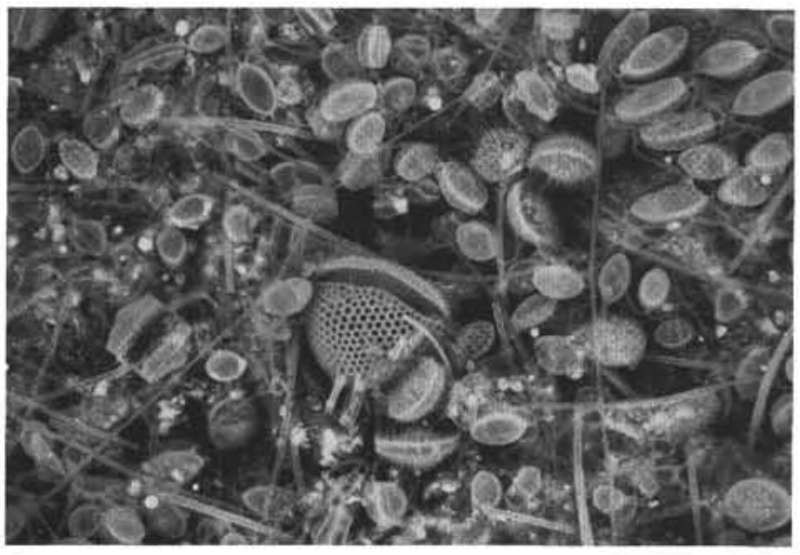

2

$50 \mu \mathrm{m}$
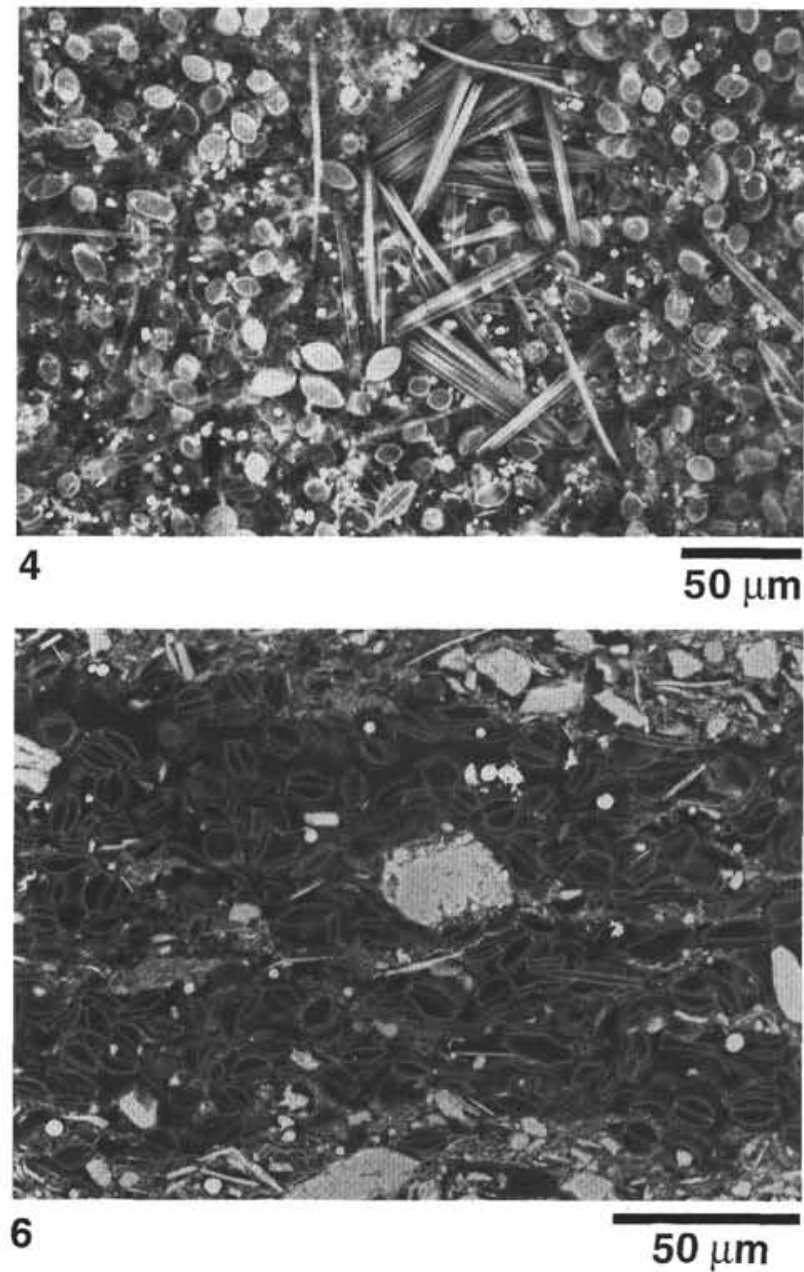

Plate I. SEM images of Chatoceros-based ooze laminae from Hole 893A. 1-4. Low-vacuum topographic backscatter images. 1. Resting stages of Chaetoceros radicans showing the characteristic high porosity of near monospecific resting spore laminae. Sample 146-893A-9H-2, 116-121 cm. 2. Mixed restingstage and setae laminae. Resting stages are primarily C. radicans and C. vanheurckii. A single Stephanopyxis turris centric diatom can be seen in the center of the image. Sample 146-893A-I IH-4, 63-67 cm. 3. Detail of an ooze lamina of varied assemblage. The resting-stage component includes $C$, radicans and $C$. vanheurckii. Small centric diatoms are represented by an example of Thalassiosira oestrupii. Debris from a larger centric diatom and abundant coccoliths are also apparent. Sample 146-893A-21H-5, 1I2-125 cm. 4. "Bundle" of Thalassionema nitzschioides in a mixed setae and resting-stage lamina. Sample 146$893 \mathrm{~A}-15 \mathrm{H}-2,96-101 \mathrm{~cm} . \mathbf{5}$, 6. High-vacuum backscatter images of polished thin sections. 5. Individual Chaetoceros resting spores within the silt-poor lamina. 6. Discrete diatom ooze laminae formed from Chaetoceros resting spores. Both from Sample 146-893A-9H-2, 116-121 cm. 

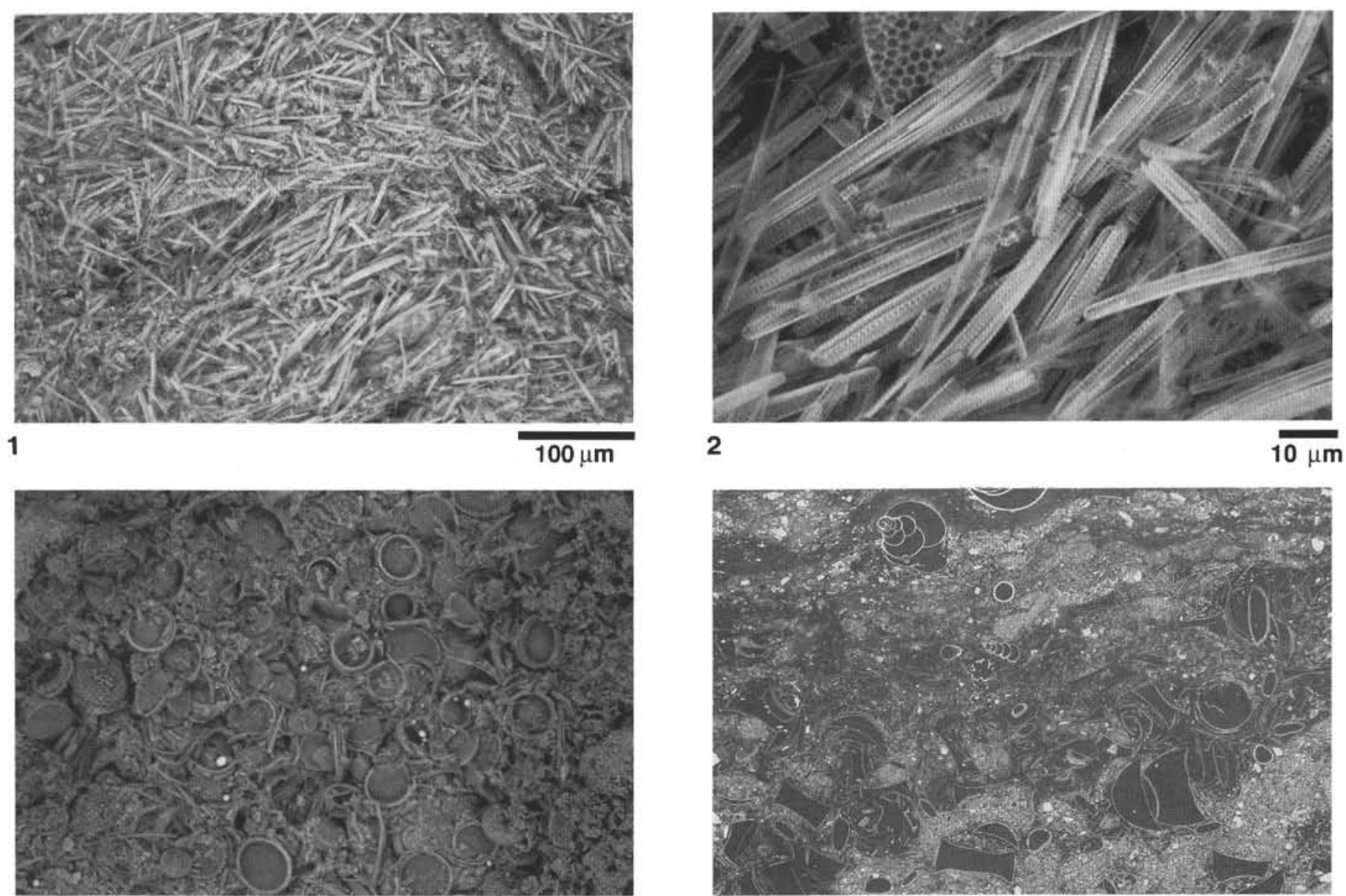

3 $50 \mu \mathrm{m}$

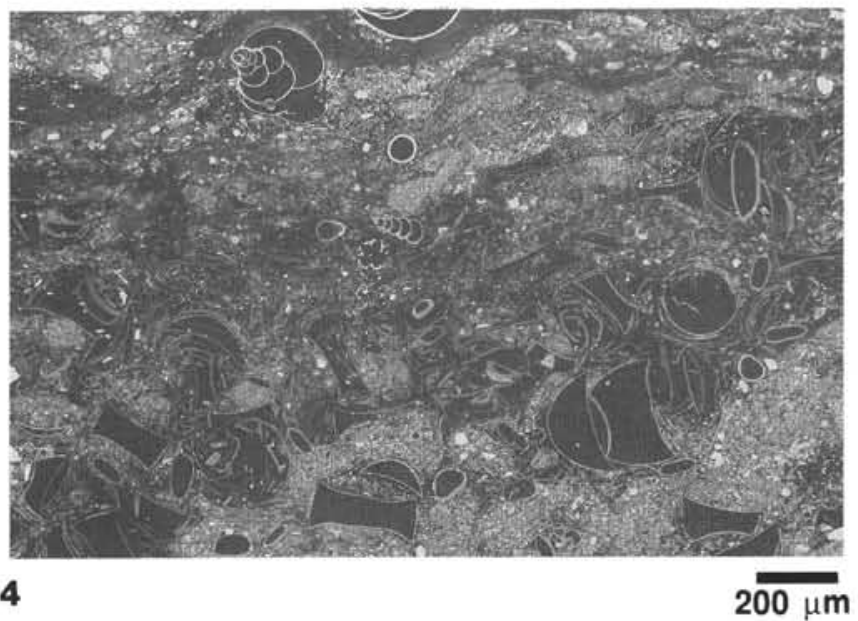

Plate 2. SEM images of non-Chaetoceros ooze laminae. 1-3. Low-vacuum topographic backscatter images. 1. Ooze lamina composed of Thalassionema nitschioides. 2. Detail of (1). Both from Sample 146-893A-15H-6, 111-114 cm. 3. Terrigenous-rich ooze lamina composed of small centric species, including Thalassiosira oestrupii. Sample 146-893A-15H-6, 42-50 cm. 4. High-vacuum backscatter image of a polished thin section showing a thick lamina composed of Coscinodiscus spp. diatoms. Sample 146-893A-1H-2, 34-46 cm. 


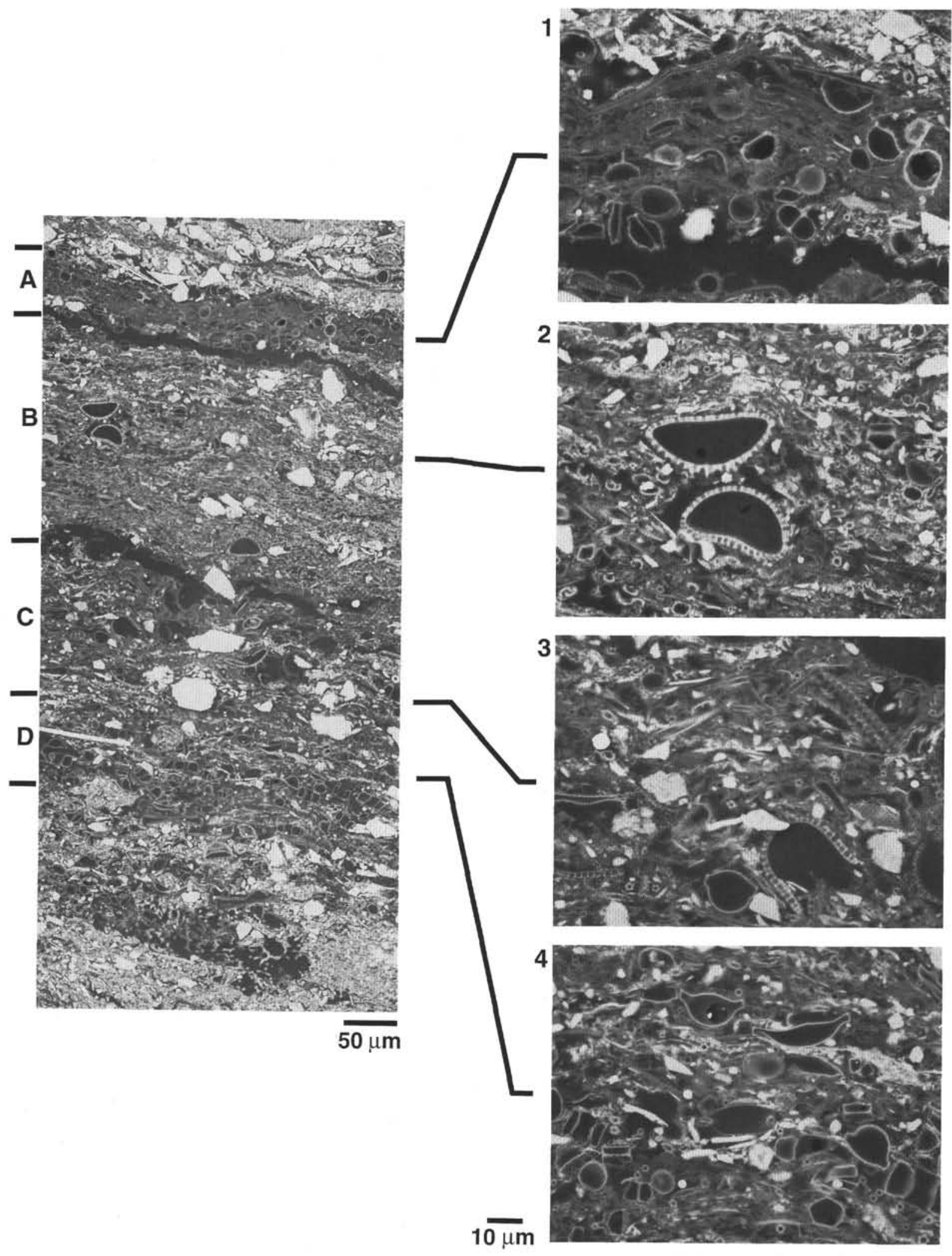

Plate 3. BSEI images of a composite ooze laminae (left) composed of four sublaminae, A through D, illustrated in detail in the right-hand images. 1. Detail of sublaminae (A) composed largely of Chaetoceros resting spores and setae. 2. Detail of sublamina (B) composed largely of Chaetoceros setae and pennate diatoms, with occasional larger centric diatoms. 3. Detail of sublamina (C) composed largely of Chaetoceros setae and debris derived from large centric diatoms. 4. Detail of sublamina (D) composed largely of resting spores and setae derived from various Chaetoceros species. Sample 146-893A-15H-3, 21-29 cm. 


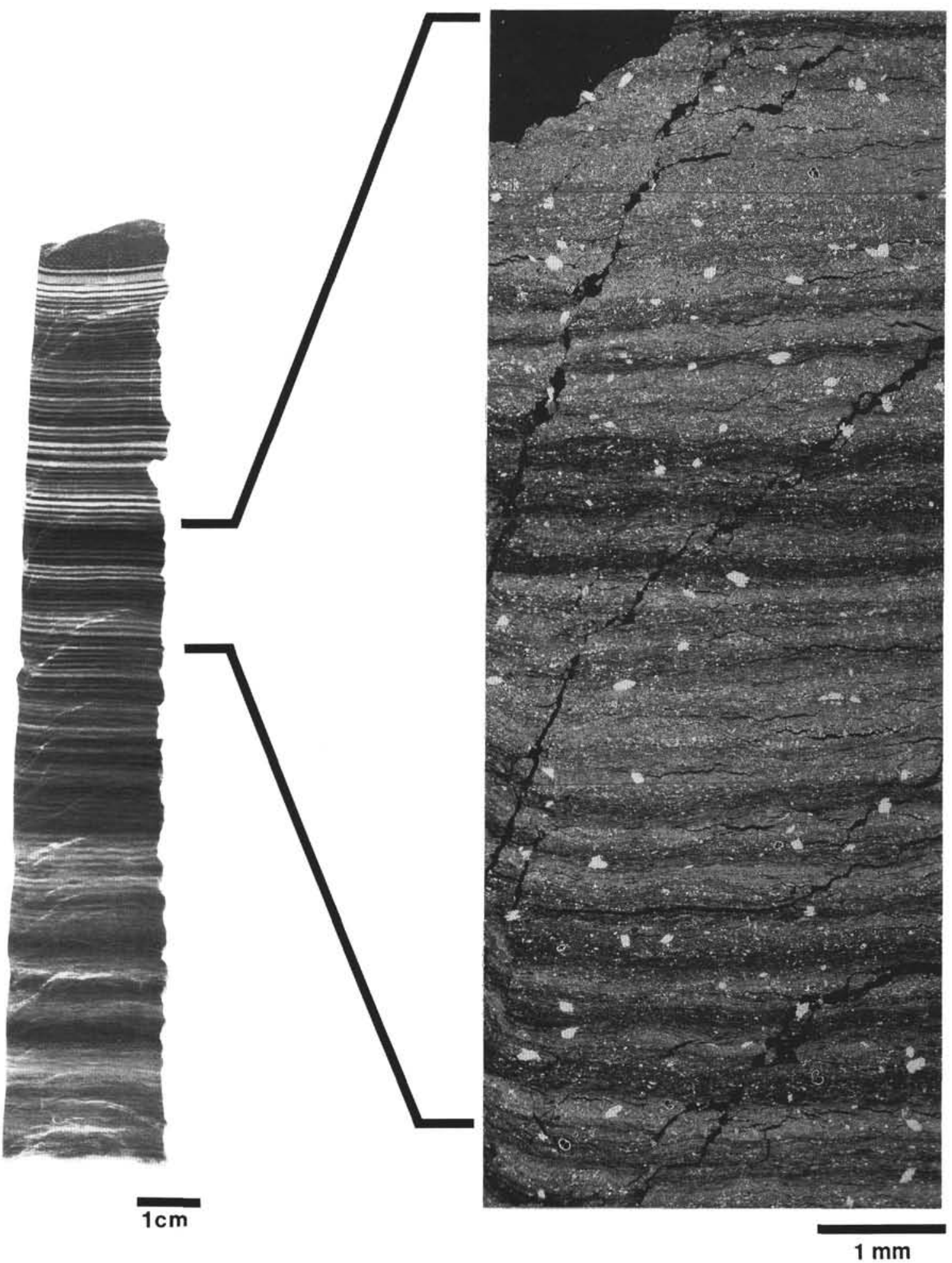

Plate 4. Comparison of X-radiograph (left) and BSE (right) images of a laminated sequence. Sample 146-893A-21H-5. $112-127 \mathrm{~cm}$. Periodic alternations between terrigenous couplet and mixed terrigenous biogenic triplet laminae styles are evident. On the X-radiograph, white laminae consist of diatom ooze, light gray laminae of silt. and darker laminae of clay. On the BSE image, dark layers correspond to the diatom ooze laminae. The upper portion of the sample is homogenized by bioturbation. The deterioration in resolution toward the base of the sequence is a reflection of a downward increase in thickness of the raw sedimentary section, rather than qualitative changes in laminae preservation. The more-detailed BSE mosaic shows that the X-radiograph image primarily reflects changes in the degree of development of diatom ooze laminae. 

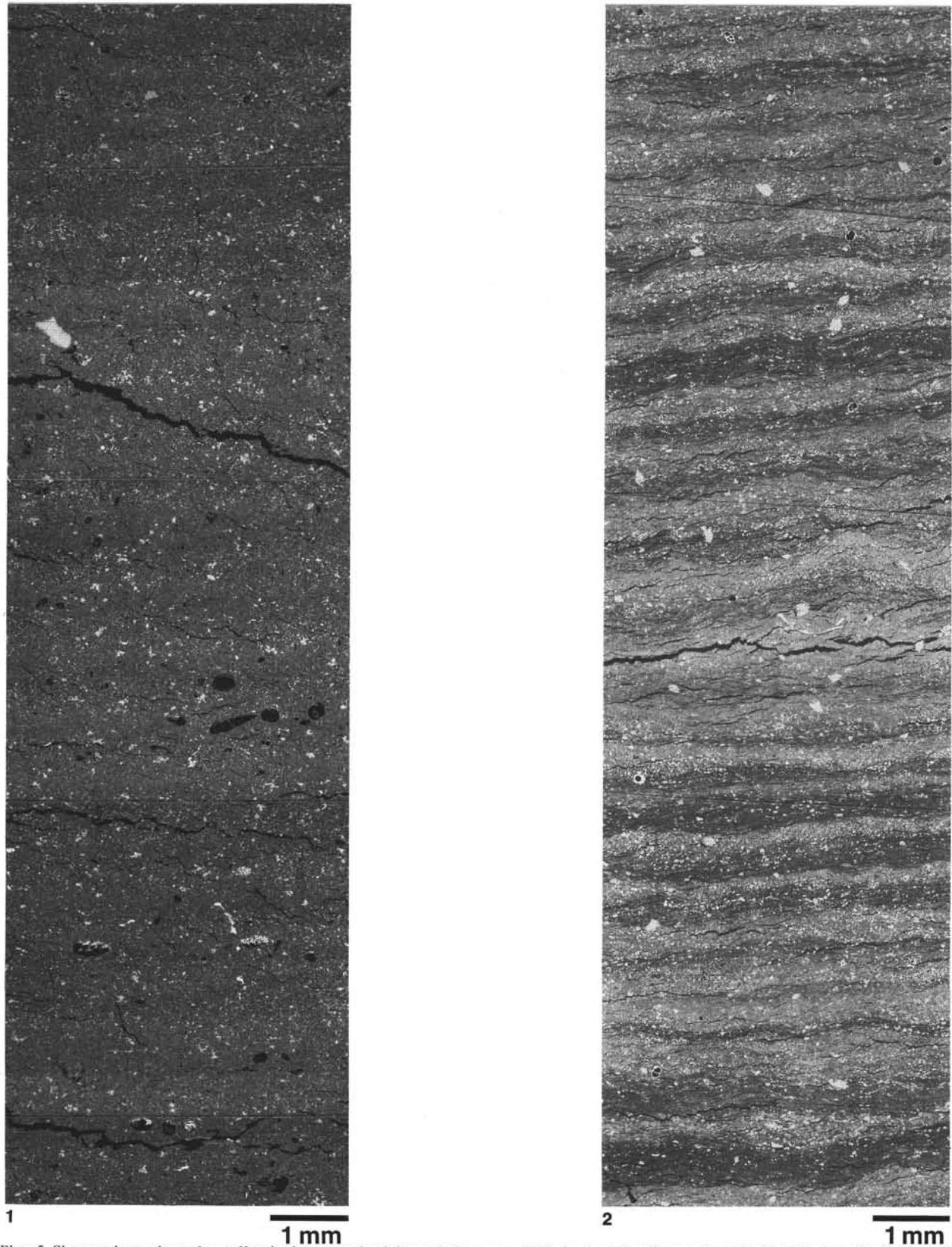

Plate 5. Short-scale continental runoff and primary productivity variations recorded in laminated sediments from the Santa Barbara Basin. 1. Variation in a terrigenous couplet laminated sequence deposited near the end of isotope Stage 6. Sample 146-893A-18H-5, 36-41 cm. The lighter packets contain a greater abundance of fine-grade material. 2. Pronounced cyclical variation in the opal content of diatom ooze laminae from Stage 6 sediments. Sample 146-893A-21H-6. 70-75 cm. Minima in opal content occur over a period of 4 to $8 \mathrm{yr}$, and may indicate reduced primary productivity during ENSO-related conditions. 